\title{
Determinants of job satisfaction of Colleges of Education Lecturers: A study of Nasarawa State College of Education, Akwanga
}

\author{
Rebecca I. Umaru ${ }^{1}$ and Danjuma A. Ombugus ${ }^{2 *}$ \\ ${ }^{1}$ Department of Art and Social Science Education, Faculty of Education, Nasarawa State University, Keffi, Nigeria. \\ 2Department of Technical Education, College of Education, Akwanga, Nasarawa State, Nigeria. \\ *Corresponding author. Email: dombugus@gmail.com. Tel: 08036041422.
}

Copyright @ 2017 Umaru and Ombugus. This article remains permanently open access under the terms of the Creative Commons Attribution License $\underline{4.0}$, which permits unrestricted use, distribution, and reproduction in any medium, provided the original work is properly cited.

Received 13th August, 2017; Accepted 5th September, 2017

\begin{abstract}
The main purpose of this study was to determine the extent of job satisfaction among the lecturers of College of Education Akwanga, Nasarawa State. The study was guided by five research questions. Descriptive research design was adopted by the study. The population for the study consisted of 279 lecturers during the 2014/2015 academic session from the six schools of the college. A sample size of the population was taken from each school using simple random sampling technique to arrive at a sample size of 167 lecturers. A structured questionnaire divided into five sections was used for data collection. The questionnaire was face validated by five experts, three in the Department of Industrial Technical Education and two from the career unit in the Faculty of Vocational Teachers Education all from the University of Nigeria, Nsukka. A reliability coefficient of 0.78 was obtained from Cronbach Alpha reliability technique to ascertain the internal consistency of the questionnaire items. The questionnaires were administered by the researchers. Mean and standard deviation were utilized to analyze the data collected, while T-test statistics was used to test the hypothesis at 0.05 level of significant. Findings of the study revealed that non regular salary payment, promotion opportunities, work environment, attainment of work goals, opportunity to growth and development among others are the determinants of job satisfaction of college of education lecturers. It is recommended that the college management should fulfill their financial obligations and make provisions for adequate facilities as this will improve lecturers' commitment to work and job satisfaction for optimal performance.
\end{abstract}

Key words: College of education, determinants, job satisfaction, Lecturers, Nasarawa State.

\section{INTRDUCTION}

Job satisfaction in Agu (2014) connote happiness and a state of well-being as an outcome of need fulfillment derived from or enjoy in one's job. A job in the context of this study means the work which one does and receives regular payment. Job satisfaction is the good feeling that you get when you have a job that you enjoy doing. In the field of organizational behavior, job satisfaction has been the most frequent studied variable. According to Wells (2011), the relevance of job satisfaction is very crucial to the growth of any education program around the globe. It probably ranks alongside professional knowledge, skills, competency, facilities and strategies as veritable determinants of educational success and performance.
Alaku (2010) encouraged researches in job satisfaction particularly among teachers in Nigeria. The author believed that findings from such researches might provide evidences that government could use in her policy formulation to improve teachers' performances for improved educational success.

Locke and Lathan (2012) defined job satisfaction as a pleasurable or positive emotional state resulting from appraisal of one's job experience. Job satisfaction is the result of an employee's perception on how well the job provides those things that are viewed as important dimensions to the worker's welfare. Hulin (2011) stated that job satisfaction is that which gives a worker a sense 
of achievement and success which is generally perceived to be directly linked to personal well-being as well as productivity. Job satisfaction is an emotional response to a job situation, as such it cannot be seen, it can only be inferred and it is often determined how well outcomes meet or exceed expectations. Factors which most significantly impede or facilitate lecturers' job satisfaction may include the following: the worker himself, salary, promotion opportunities, work environment, supervisory style and co-worker relationship. Armstrong (2009) agreed that company policies, salary, co-worker relationship, supervisory/management style and work environment were determinants of workers' job satisfaction.

According to Oshegbemi (2003), organizations that have goals achieved must have satisfied and happy staff in their workforce. Obwogi (2011) explained that for any College of Education to take off, achieve, and sustain her goals, the College must depend on her capacity to attract, retain and maintain competent and satisfied staff into her employment. The College being an institution of higher learning that provides manpower needs to advance national development must itself be capable of ensuring adequate manpower planning and development. It should therefore not afford to neglect the needs and essentials aspects of her workforce welfare. The workforce of college of education Akwanga consists of male and female lecturers. It is evident that gender issues go a long way in shaping or determining what a lecturer (male or female) will consider as job satisfying or not satisfying. Gender in UNICEF (2011) is described as the process by which individuals are born, who are born into biological categories of male and female, and become the social categories of locally defined attributes of masculinity and femininity. Gender is always being employed to refer to mere societal perceptions of the differences in males and females. In the context of this study, gender is seen as a social construct used in classifying roles/interest and relationships of men and women across various cultural groups. Gender implies the socially approved construct of being male and female. It is pertinent to note that gender issues are very crucial in any institution such as the College of Education, Akwanga.

College of Education Lecturers are currently facing many challenges in form of inadequate infrastructure, non regular payment of salaries, lack of enabling research environment and disparity in salary and allowances which have resulted into industrial action by the lecturers over years. Inconsistent policy implementation between federal and state governments may as well affect lecturers' level of job satisfaction (Ombugus, 2013). In many instances, academic programmes are distorted because management takes certain decisions without involving lecturers. This in turn creates additional work dissatisfaction.

The consequence of lack of job satisfaction in the college of education set-up is the shortage of competent and committed lecturers. Reports from the National Commission for Colleges of Education (NCCE, 2012) revealed that while the numbers of Colleges of Education are increasing, the numbers of qualified lecturers are not increasing proportionately. There has been constant mobility of these highly skilled persons from one college of education to another and to other public sectors for better remuneration and conducive working environments. Other factors that mitigate job satisfaction include management and leadership styles, nonacademic duty allowance, unclear rules and regulations in the personnel policies, excessive workload and poor communication with management members.

This study is hinged on the motivator-hygiene theory also called "The two factor theory". According to Herzberg (1989), the theory states that employees are motivated by internal values rather than values that are external to work. In other words, motivation to work is internally generated and is propelled by variables that are intrinsic to work which includes achievement, recognition, the nature of the work itself, responsibility, and advancement or growth. The most important motivatorhygiene theory factor that contributes to job satisfaction or organizational performance is inter-personal relationship. Mean-while responsibility and opportunities for promotion was ranked by Chew (2004) as the important motivating factors that affect job satisfaction. Adeyemi (2015) concluded that job satisfaction is also related to motivation. Employers need to create and maintain a conducive and enjoyable working environment to motivate the employees.

Rosser (2006) pointed out that salary, retirement benefit and job security are important personal issues that affect job commitment and satisfaction of College of Education Lecturers. In Tettey (2008), dissatisfaction with salaries is one of the factors undermining the commitment of lecturers to their institutions and careers and consequently their decision to leave job. Okpara (2014) stated that providing conducive working environment could lead to higher organizational commitment through a variety of reasons. Stressful working environment results to low level of commitment and dissatisfaction. Good working conditions such as clean, attractive surroundings enable employees to perform their work smoothly and thus are likely to have a positive impact on Job Satisfaction. A study by Dockel (2010) found out that the general working conditions were significantly related to organizational commitment. Research studies have also found job security to be positively related to job satisfaction (Ombugus, 2013). The existence of job security is likely to boost employees' perceptions of organizational support which would help to foster organizational commitment. Thus, it was hypothesized that there would be a positive relationship between satisfaction with job security and organization commitment. In Grunberg and Tapfield (2009), promotion and tenure are control variables of lecturers' job 
satisfaction. The authors stated that promotion is a highly predictor of job satisfaction among college of Education Lecturers. Similarly, Bender and Heywood (2012) explained that tenured college lecturers tend to have higher job satisfaction level than untenured lecturers.

In Dockel (2010), autonomy refers to increased feelings of personal responsibility and the degree to which the job provides substantial freedom, independence and discretion to the individual to schedule work and determine the procedures use in carrying it out. Lecturers' autonomy refers to their ability to decide work patterns, actively participate in major academic decision making to have work evaluated by professional peers and to be relatively free of bureaucratic regulations and restrictions (Daly, 2009). Employees expect to work in jobs that provide them with opportunities to be promoted to new and challenging positions. Dockel (2010) strongly argued that people should not only be rewarded financially but they should also be offered opportunities to grow within the organization. Employees who feel stagnant in their position generally are not motivated and committed and in some cases quiet the job. Promotion offers opportunity for growth and is also one of the motivators which can be used to enhance retention. Research findings by Ukeje and Ugwuanyi (2011) revealed that positive relationship exists between organizational commitment and training opportunities. On the basis of the above reviews, one can argue that the higher the employee gets satisfaction with each facet of the job, the greater the sense of commitment to the organization. To improve the work out of lecturers in the college of education Akwanga, their job satisfaction must be determined, hence the purpose of this study.

\section{Purpose of the study}

The main purpose of this study therefore, was to determine the extent of job satisfaction among the lecturers of College of Education Akwanga, Nasarawa State. Specifically, the study determined the extent to which:

1. Salary affect job satisfaction of lecturers in college of education Akwanga.

2. work environment affects job satisfaction of lecturers in college of education Akwanga.

3. job security affects job satisfaction of lecturers in college of education Akwanga.

4. autonomy of colleges of education affect job satisfaction of lecturers in college of education Akwanga.

5. staff training affect job satisfaction of lecturers in college of education Akwanga.

\section{Research Questions}

The study was guided by five research questions:
1. To what extent do salaries affect lecturers' job satisfaction in college of education Akwanga?

2. To what extent do work environment affect lecturers' job satisfaction in college of education?

3. To what extent do job securities affect lecturers' job satisfaction in college of education Akwanga?

4. To what extent does autonomy of college of education affect lecturers' job satisfaction in college of education Akwanga?

5. To what extent does staff training affect lecturers' job satisfaction in college of education Akwanga?

\section{Hypothesis}

$\mathbf{H}_{\mathbf{o}}$ There is no significant difference in the mean responses of the male and female lecturers on their job satisfaction level in college of education Akwanga.

\section{METHODOLOGY}

The research design employed for the study is a descriptive survey research design. Okpara (2014) defined a survey as a description of a present state of affairs usually carried out through questionnaires; opinions and interviews. The study was conducted in College of Education, Akwanga, Nasarawa State. The population for the study was two hundred and seventynine (279) lecturers as shown in Table 1.

The researchers used a simple random sampling technique to select $60 \%$ of the population from each school. A sample size of 167 Lecturers was utilized for the study. A structured questionnaire (Lecturers Job Satisfaction Questionnaire, LJSQ) was used for data collection. The questionnaire had five sections based on the purposes of the study. Mean and standard deviation were employed to analyze the data collected and answer the research questions using the real limit of the mean.

\section{RESULTS}

Research Questions 1: To what extent do salaries affect lecturers' job satisfaction in college of education Akwanga?

The data in Table 2 revealed that the 6 items had their $\bar{X}$ values ranged from 3.58 to 4.04 and were greater than 2.50. This indicated that the 6 items were affecting motivation, commitment and productivity among college lecturers. The standard deviations ranged from 1.33 to 1.62 and are positive. This indicated that the respondents were not very far from the mean or one another in their responses. This helped to add value to the mean.

Research Question 2: To what extent do work environment affect lecturers' job satisfaction in college of education Akwanga? 
Table 1. Population of Lecturers in the College during 2014/2015 Academic Session.

\begin{tabular}{clc}
\hline S/No & School & No. of Lecturers \\
\hline 1 & School of Education (SE) & 68 \\
2 & School of Early Childhood Care and Education (ECCE) & 20 \\
3 & School of Secondary Education - Art \& Social Science Programmes (SSEASSP) & 62 \\
4 & School of Secondary Education - Language Programme (SSELP) & 35 \\
5 & School of Secondary Education - Science Programme (SSESP) & 40 \\
6 & School of Secondary Education - Vocational \& Technical Programmes (SSEVTEP) & 54 \\
& Total & 279 \\
\hline
\end{tabular}

Table 2. Mean responses of the lecturers on the extent of effect of salary on job satisfaction $\quad \mathrm{N}=167$.

\begin{tabular}{clccc}
\hline S/No. & Questionnaire Items & $\overline{\boldsymbol{X}}$ & SD & Remark \\
\hline 1 & Fulfillment of financial and motivational desires & 3.62 & 1.33 & Agreed \\
2 & Affects job motivation & 3.81 & 1.35 & Agreed \\
3 & Affects job commitment & 4.04 & 1.62 & Agreed \\
4 & Affects job productivity & 3.58 & 1.57 & Agreed \\
5 & Reduces absenteeism from work & 4.03 & 1.47 & Agreed \\
6 & Reduces withdrawal from job & 3.78 & 1.43 & Agreed \\
\hline
\end{tabular}

$\bar{X}=$ mean S.D $=$ Standard deviation.

Table 3. Mean responses of the Lecturers on the extent of effect of work environment on Job Satisfaction $\mathrm{N}=167$.

\begin{tabular}{clccl}
\hline S/No. & Questionnaire Items & $\overline{\boldsymbol{X}}$ & SD & Remark \\
\hline 7 & Affects job commitment & 4.33 & 1.72 & Agreed \\
8 & Affects motivation & 2.16 & 1.04 & Disagreed \\
9 & Affects job efficiency & 4.02 & 1.66 & Agreed \\
10 & Reduces physical/psychological stress & 3.78 & 1.49 & Agreed \\
11 & Provision of adequate working facilities & 3.96 & 1.36 & Agreed \\
12 & Good interpersonal relationship & 2.23 & 1.11 & Disagreed \\
13 & Affects job productivity & 2.35 & 1.07 & Disagreed \\
\hline
\end{tabular}

The data collected (Table 3) revealed that items 7, 9, 10 and 11 had their mean values ranged from 3.78 to 4.33 and are above decision point of 2.5. This indicates that work environment affect job commitment, efficiency, psychological stress as well as provision of working facilities. Similarly, the data revealed that items 8,12 , and 13 had their mean values below decision point (2.50) indicating that work environment has less effect on job motivation, good interpersonal relation and productivity.

Research Question 3: To what extent do job securities affect lecturers' job satisfaction in college of education Akwanga?

The responses from the lecturers revealed that items 14 , $15,17,18$ and 19 had their mean values above the decision point of 2.50 (Table 4). This indicated that job security affects dismissal from work, job motivation, increases feeling of being a lecturer, while item 16 which fosters job commitment does not affect job security with a mean value of 1.41 lower than 2.50 .

Research Question 4: To what extent does autonomy of colleges of education affect lecturers' job satisfaction in college of education Akwanga?

The results obtained revealed that items $20,23,24$ and 25 had mean values above 2.50 (Table 5). This indicated that autonomy affects job motivation, commitment, increases feeling of belonging and job efficiency, while items 21 and 22 had their mean values below decision point indicating that autonomy does not necessarily affects job productivity and opportunity for growth.

Research Question 5: To what extent do staff training affect lecturers' job satisfaction in college of education Akwanga? 
Table 4. Mean responses of the Lecturers on the extent of effect of job security on job satisfaction $\mathrm{N}=167$.

\begin{tabular}{clccl}
\hline S/No. & Questionnaire Items & $\overline{\boldsymbol{X}}$ & SD & Remark \\
\hline 14 & Decreases dismissal from work & 3.68 & 1.59 & Agreed \\
15 & Affects job motivation & 4.43 & 1.58 & Agreed \\
16 & Fosters job commitment & 2.14 & 1.41 & Disagreed \\
17 & Increases the feeling of being lecturers & 4.14 & 1.36 & Agreed \\
18 & Makes lecturers lazy & 4.28 & 1.56 & Agreed \\
19 & Affects job efficiency & 4.16 & 1.56 & Agreed \\
\hline
\end{tabular}

Table 5. Mean responses of the lecturers on the extent of effect of autonomy on Job Satisfaction $N=167$.

\begin{tabular}{clccl}
\hline S/No. & Questionnaire Items & $\overline{\boldsymbol{X}}$ & SD & Remark \\
\hline 20 & Affacts job commitment & 4.72 & 1.78 & Agreed \\
21 & Affects job productivity & 2.12 & 0.47 & Disagreed \\
22 & Offers opportunity for growth & 1.87 & 0.39 & Disagreed \\
23 & Affects motivation & 4.11 & 1.39 & Agreed \\
24 & Increases the feeling of personal belonging & 3.96 & 1.35 & Agreed \\
25 & Affects job efficiency & 3.88 & 1.54 & Agreed \\
\hline
\end{tabular}

As indicated in Table 6, the results revealed items 26, 27, $29,30,31,32$, and 33 with mean values higher than decision point. By implication, staff training improves job deficiencies, productivity, commitment and promote personal and professional growth. On the other hand, item 28 had a mean value lower than the decision point, indicating that staff training does not affect retention of college lecturers. The standard deviations of the 28 items in Tables 3 to 6 ranged from 0.39 to 1.78 and are positive. This indicated that the respondents were not very far from the mean or one another in their responses. This helped to add value to the mean.

Ho: There is no significant difference in the mean responses of male and female lecturers in college of Education Akwanga with regard to their job satisfaction.

Table 7 showed that the table value (t-value) is 2.02 at 808 degree of freedom and 0.05 level of significant. Since the calculated t-value of 1.96 is less than the table value of 2.02, the null hypothesis is accepted. Therefore, there was no significant difference between the mean responses of male and female lecturers in college of education Akwanga with regards to their job satisfaction level.

\section{Major findings}

1. Salary/Wage payment decreases absenteeism and withdrawal from job. It also has effects on commitment, productivity and motivational desires on job satisfaction of lecturers in College of Education, Akwanga.
2. In the College of Education, Akwanga, work environment affect lecturers job satisfaction in commitment, efficiency, psychological stress and facilities but does not necessary affect the lecturers' motivation, interpersonal relationship and productivity.

3. Apart from "Fosters job commitment" job security has effects on dismissal from work, motivation, feeling of belonging, efficiency and laziness on job satisfaction of lecturers in College of Education, Akwanga.

4. Autonomy affects commitment, motivation, feeling of belonging and efficiency but does not necessarily affect opportunity for growth and productivity on job satisfaction of lecturers in College of Education, Akwanga.

5. Excluding job retention, staff training affects efficiency in performance, quality and quantity of human resources, achievement of organizational goals, productivity, commitment, professional growth and motivation on job satisfaction of lecturers in College of Education, Akwanga.

6. There was no significant difference in the mean responses of the male and female lecturers regarding their level of job satisfaction.

\section{DISCUSSION}

The findings from the study that all the items accepted by the respondents in research question one are in agreement with Rosser (2006) who stated that attractive remuneration packages are one of the important factors of staff retention. Dissatisfaction with salaries/benefits is one of the key factors undermining the commitment of 
Table 6. Mean responses of lecturers on the extent of effect of staff training on job satisfaction $\mathrm{N}=167$.

\begin{tabular}{clccl}
\hline S/No. & Questionnaire Items & $\overline{\boldsymbol{X}}$ & SD & Remark \\
\hline 26 & Overcomes deficiencies in job performance & 3.22 & 1.78 & Agreed \\
27 & Production of quality and quantity of human resources & 3.62 & 1.47 & Agreed \\
28 & Enhances job retention & 2.22 & 1.46 & Disagreed \\
29 & Enhances job productivity & 4.11 & 1.53 & Agreed \\
30 & Affects job commitment & 4.11 & 1.39 & Agreed \\
31 & Promote job motivation & 3.96 & 1.36 & Agreed \\
32 & Achievement of organizational goal & 3.88 & 1.54 & Agreed \\
33 & Promotes personal and professional growth & 3.90 & 1.31 & Agreed \\
\hline
\end{tabular}

Table 7. T-test of male and female lecturers in college of education Akwanga with regard to their job satisfaction $(\mathrm{N}=167)$.

\begin{tabular}{lccccccc}
\hline Gender & $\mathbf{N}$ & $\overline{\boldsymbol{X}}$ & SD & DF & t-cal & Table t & Decision \\
\hline Male & 117 & 35.43 & 0.32 & 808 & 1.96 & 2.02 & Significant \\
Female & 50 & 36.60 & 0.47 & & & & \\
\hline
\end{tabular}

College of Education lecturers and consequently decision to leave their jobs. The findings that four items in research question 2 were accepted by the respondents were in agreement with Daly (2009) who suggested that working environment is also one of the factors that affect employee's decision to stay with an organization. Productivity and efficiency are directly affected by how people work, and this equally is affected by their work environment/condition. Work environment that is comfortable, relatively low in physical/ psychological stress and good facilities, attainment of goals in such workplace tends to give high level of job satisfaction. Increased workload is another stressful aspect of lecturer's job. An increase workload caused by large number of students without proportionate increase in wages certainly has negative impact on the well-being of College of Education Lecturers.

The findings of the study on the effect of job security are in agreement with the work of Ukeje and Ugwuanyi (2011). In their study, "Effects of Job Insecurity on the Psychological Health of Company Workers-Implication for Colleges of Education Workers in Nigeria", they revealed that there were strong relationships between job security and job satisfaction. The existence of job security is likely to boost employee's perception of organizational support which would help to foster job satisfaction. The findings indicated that in most cases the employees in Colleges of Education (irrespective of sex and age) who perceived that they have uncertain futures in their jobs, felt threatened with manifested symptoms of psychological distress such as poor general health, anxiety and hopelessness.

The findings of this study on the effect of autonomy are in line with the findings of Adeyemi (2015) in a study "Job satisfaction among Technical Teachers in Ondo State
Secondary Schools that the autonomy of Colleges of Education tends to instill in the lecturers sense of belonging in the school activities. The lecturers believed that autonomy means bringing government closer to them in the college to reduce their burden of travelling long distances to the parent ministry. The autonomy is an important construct in Colleges of Education Lecturers' value system. Lecturers in Colleges of Education tend to stay longer in their institutions when they feel that their capabilities, efforts, performance, contributions are recognized and appreciated by government timely.

The findings of this study on the effect of staff training on College of Education lecturers' job satisfaction are in conformity with the findings of Alaku (2010) that training is considered a form of human capital investment whether that investment is made by the individual or by the firm. Training provides employees with specific skills to help correct deficiencies in staff performances. Development on the other hand is an effort to provide employees with skills the organization will need in the future. Staff retraining programme is therefore a necessary factor for lecturers' optimal performance. The findings of the study were also in agreement with the work of Ombugus (2013) in a study "Improving Job Satisfaction of Primary School Teachers in Nasarawa State, where it was found that primary school teachers could not perform optimally in their duties because of non-regular payment of salaries. It was also found that there was no significant difference in the mean responses of the male and female lecturers on their job satisfaction level. This finding was in agreement with that of Bender and Heywood (2012) in a study on Job satisfaction of the highly educated, the role of the gender, academic tenure and earnings, where significant difference did not exist between the male and female respondents. 


\section{Implications of the study}

The findings of this study have the following implications:

1. If lecturers are satisfied in their job, their output could increase. Parents' observation that their wards are not well taught in the college could now assume a very low magnitude.

2. If the state government can holistically address the identified determinants of job satisfaction of lecturers in this study, the teaching could become more reliable as all the expected curriculum contents will be covered.

3. If college lecturers are satisfied in their job, they would be self-fulfilled that the objectives of teacher education could be achieved and they could be confident that the students have acquired skills in teaching.

\section{Conclusion}

Consistency to job commitment and productivity, attainment of work goals, fulfillment of financial and motivational desires, provision of needed facilities, opportunity for growth and development and feeling of personal belonging among others are fundamental determinants of job satisfaction of lecturers in College of Education, Akwanga. Therefore, Colleges of Education Lecturers need adequate educational policy and administration in terms of the identified determinants for the lecturers to be satisfied in their job. When lecturers are meeting their basic needs in life such as food, clothing and healthcare, they perform optimally in workplace.

\section{Recommendations}

1. The College Management should ensure that wages/benefits for Academic Staff are paid as at when due.

2. The working environment of lecturers should be made conducive for teaching and research work.

3. The College Management should provide job security and design a staff training plan for all categories of academic staff members.

\section{CONFLICT OF INTEREST}

The authors declare that they have no conflict of interest.

\section{REFERENCES}

Adeyemi, B. A. (2015). Job Satisfaction among Technical Teachers in Ondo State Secondary Schools. Journal of Teacher Perspective, 10(1), 68- 76.

Agu, L.U, (2014). Job Satisfaction Factors of Primary School Teachers - A case study of Nasarawa State. Nigeria Vocational Association Journal, 19(2), 117-127.

Alaku, G. Y. (2010) Job Satisfaction among Metal Work Teachers in Technical Colleges in Nasarawa State. The
Nigerian Teacher (TODAY). A Journal of Teacher Education Published by the National Commission for Colleges of Education. 13(1), 30-39.

Armstrong, M. A. (2009). Handbook of Human Resource Management Practice, London: Kogan page Limited.

Bender, K. A., \& Heywood, J. S. (2012). Job Satisfaction of the Highly Educated: The Role of Gender, Academic Tenure, and Earnings. Scottish Journal of Political Economy, 53(2), 253279.

Chew, J. C. (2004). The Influence of Human Resource Management Practices on the Retention of Core employees of Australian Organisations: Ph.D Thesis. Murdoch University.

Daly, C. L. (2009). Greener Pastures: Faculty Turnover Intent in Urban public Universities. Journal of Higher Education, Development Conference Proceedings, 2(9), 1305-1313.

Dockel, A. (2010). The Effect of Retention Factors on Organizational Commitment: An Investigation of High Technology Employees. Master of Human Resource Thesis.University of Pretoria.

Grunberg, D \& Tapfield, S. F. (2009). An index of job satisfaction. Journal of Applied Pschology, 35, 307-311.

National Commission for Colleges of Education (2012). The Minimum Standard for Nigeria Certificate in Education, $4^{\text {th }}$ edition. Abuja, NCCE.

Herzberg, U. (1989). The Motivation to work. New York: John Willy and Sons Limited.

Hulin, C. (2011). Alienation, Environmental Characteristics and Workers Responses. Journal of Applied Psychology, 5(1), 284-290.

Locke, E. A., \& Lathan, G. P. (2012). Theory of goal setting and Task Performance. Englewood Cliffs, Prentice - Hall, Pp. 248-250.

Obwogi, J. (2011). Factors that Affect Quality of Teaching Staff in Universites in Kenya, Ph.D Thesis, .Jomo Kenyatta University of Agriculture and Technology.

Okpara, J. O. (2014). Job satisfaction and organizational commitment: Are there differences between American and Nigerian managers employed in the US MNCs in Nigeria? Paper presented at the Academy of Business and Administrative Sciences (ABAS) International Conference, Montreux, Switzerland.

Ombugus, D. A. (2013). Improving Job Satisfaction of Primary School Teachers in Nasarawa State:Implication for the Universal Basic Education Programme. Nigeria Vocational Association Journal, 9(1).147-155.

Oshegbemi, T. (2003). Personal Correlates of Job Satisfaction: Emperical evidence from UK Universities. International Journal of Social Economics, 30(12), 1210-1232.

Rosser, V. (2006). Faculty Members' Intention to Leave. A national study on their work - life and satisfaction, Research in Higher Education, 45(3), 285-309.

Tettey, J. W. (2008). Staff Retention in African universities: Elements of a Sustainable Strategy, Washington, DC: World Bank.

United Nations Children Education Fund (2011). Gender and Development: Awareness and Sensitization in Nigeria. Nigeria: UNICEF

Ukeje, A. E., \&Ugwuanyi, C. L. (2011).Effects of Job Insecurity on the Psychological Health of Company WorkersImplications for Colleges of Education Workers in Nigeria.Journal of Educational Leadership, 14(1), 50-56.

Wells, J. (2011). Teacher Responses to Pay-for-Performance Policies". Survey Results from Four High-Poverty Urban School Districts. Winthrop Publishers, 45(2), 139-176. 